Предраг М. ЈАШОВИЋ* Државни универзитет у Новом Пазару Департман за филолошке науке
Оригинални научни рад

Примљен: 05. 10. 2016. Прихваћен: 10. 02. 2017.

\title{
МАРКО ЦАР, КА ТЕОРИЈСКОЈ И ЖАНРОВСКОЈ ДЕФИНИЦИЈИ ЕСЕЈА
}

Марко Цар (1856-1953) је већ по дужини живота занимљив. Он је, како истиче П. Палавестра, књижевну каријеру започео нешто старији од В. Илића, а завршио ју је као савременик В. Попе и М. Павловића. Мишљења смо да, поред тога што је дужина његовог живота допринела богатом књижевнокритичком опусу, услед мењања стваралачких и аксиолошких погледа на књижевност, припомогла је и да он буде препуштен забораву као књижевни критичар.

У раду тежимо да сагледамо колико је Марко Цар, поред, рецимо, И. Секулић и Б. Лазаревића, допринео развоју есејистике и утврђивању овог жанра у српској књижевности. То омогућава његова књига Есеји (1936) у којој је поделом садржине на три дела показао стваралачку тежњу да теоријски одреди жанр есеја и да га прикаже у неким од његових основних манифестационих облика, не по тематици, колико према начину захватања проблема. Занимљиво је да у неколико есеја, интровертним сагледавањем сопственог креативног чина, истиче сврсисходност саме есејистике. Зато ова књига представља и аутопоетичку књигу, која не уводи само у стваралачки поступак овог књижевног критичара, већ и у основе његовог аксиолошког система. Стога сматрамо да је ова књига кључна за разумевање књижевнокритичког рада Марка Цара у целини.

Кључне речи: Марко Цар, есеј, књижевна критика, жанр.

Марко Цар (1859-1953) је један од оних књижевних критичара који је дао значајан допринос укупном развоју књижевне критике у српској књижевности, а који су данас остали скрајнути. О њима се ретко говори, још ређе пише. Марко Цар није унео преврат у књижевну критику. Он није био творац методе или аксиолошких мерила; припадао је плејади књижевних критичара који су деловали у оквирима књижевнокритичког доба које се одређује као Скерлићево. Према томе се и одређују домети његових књижевнокритичких ставова и вредносних оцена. Стварао је књижевну критику и есејистику, што je, рекли бисмо од превасходног значаја, раме уз раме са Јашом Продано-

\footnotetext{
*pjasovic@gmail.com
} 
вићем, Слободаном Јовановићем, Миланом Гролом, Васом Стајићем, Владимиром Ћоровићем и другима.

Чини се да су у историји српске књижевности остала подељена мишљења о његовом значају и раду, а да његово дело није ни изблиза сагледано у целини. Ми ћемо у овом нашем раду тежити да покажемо значај књижевнокритичког рада овог књижевног критичара, како у области књижевне критике, тако и у области стварања есеја као књижевног жанра.

Већ Историјом српске књижевне критике (2008) Предрага Палавестpe, Марко Цар бива потврђен као књижевнокритичка чињеница у српској науци о књижевности. Кроз књижевну историју о Цару, као књижевном критичару, пратимо супротстављене оцене и ставове. У својој актуелности он је био признат и познат. Већ за то време је био толико заслужан да се својим књижевнокритичким радовима нашао у првој Антологији српске критике (1929), коју је сачинио Љубомир Петровић, а Цара поставио одмах уз најзначајнија имена као што су: Вук Стефановић, Светислав Вуловић, Слободан Јовановић, Милан Грол, Светозар Марковић, Љубомир Недић, Андра Николић, Богдан Поповић, Павле Поповић, Јован Скерлић. То потврђује да Марко Цар у својој актуелности није био маргинална фигура, нити је као књижевни критичар залутао у памћење историје српске књижевности. Међутим, иако је Цару Љубомир Петровић дао, рекли бисмо, чак, почасно место, јер га је у антологију уврстио радом о Његошу, Царев стил овако оцењује: „Његов стил има две крупне мане: велики број покрајинских, и још већи и непотребнији број страних речи" (Петровић 1929: 93). Дакле, Марко Цар је истицан и поштован, али није само хваљен нити су му грешке праштане.

У првој историји нове српске књижевности, Јован Скерлић не изоставља Марка Цара. Истиче га као свог савременика. Сматра да је од значаја што је Марко Цар наставио да се бави праћењем и тумачењем стране књижевности, што је пре њега радио Светомир Николајевић. Сматра да је белетристику стварао са познавањем књижевног заната, али без књижевног талента (Скерлић 1953: 418). Његов књижевнокритички рад оцењује овако:

Где је реч о страним писцима, Цар је без оригиналности и често се дословце ослања на оно што су други писали. Много је бољи, самосталнији и кориснији када пише о домаћим писцима, нарочито о далматинским писцима новога доба. Иначе, књижевно образован, жива духа, лак на писању, он је умео да буде занимљив и да стече читаоце (Скерлић 1953: 418).

Као и у случају многих других писаца и ова се Скерлићева оцена доста дуго скоро преписивала. Тако у јединој потпунијој историји српске књижевности, од оне Скерлићеве, Јован Деретић овако оцењује Цара:

[...] највише је радио на есеју из страних књижевности [...] Био је аматер, на старински начин одушевљен књижевношћу, без дубине изворности, просветитељ и популаризатор који је утицао на књижевно образовање читалаца, на подстицање њиховог занимања за стране и домаће писце (Деретић 1983: 439).

Предраг Палавестра је дао једну обухватнију оцену књижевнокритичког рада Марка Цара, добрим делом се руководио оценом коју је раније дао 
Драгиша Витошевић. Палавестра истиче да је, можда и због дужине живота, Марко Цар био усамљена појава у српској књижевној критици, јер је почео као савременик Војислава Илића, а завршавао је као савременик Васка Попе и Миодрага Павловића.

Човек отвореног и радозналог духа, космополита и естета лепе културе и господственог држања, приповедач, есејиста и путописац који цени класичну лепоту, Цар је био критичар грејан просветитељским жаром, љубављу према књизи и лепој речи, добрим намерама и књижевним симпатијама, али без довољно система и истрајности у уверењима (2008: 205).

Неистрајност му се често спочитавала јер је у време превласти реалистичког правца у књижевности истицао умереност и значај лепоте у књижевности нагињући ка естетизму генерација које долазе. После Првог светског рата, потпуно супротно очекивањима, он се окренуо против авангардних песника и нападао их је где год је стигао. Што је у неку руку разумљиво, јер је суштински припадао Скерлићевој епохи књижевног укуса, вредновања и поимања књижевних чињеница. Да је поступио другачије, сигурно не би изневерио очекивања књижевних историчара, али би изневерио себе.

Најобухватније је рад Марка Цара обрадио Драгиша Витошевић у капиталној едицији Српска књижевна критика у 25 књига у књизи 10, коју је Витошевић насловио као Критика у Скерлићево доба, у предговору књизи највише простора даје Марку Цару. Мада неприметно, али је Цар, сматрамо не случајно, заступљен највећим бројем радова. Сврстава га у најстарији нараштај српске „нове критике” уз Љубомира Недића и Богдана Поповића (Витошевић 1975: 9). Витошевић истиче Цара као посебног ствараоца за време у коме је историјски ситуиран његов рад: „на први поглед скоро сви 'прави' критичари (јер сем Цара, нису били ни песници ни приповедачи ни слично), они су још много што друго, и чак понајпре то друго, тако да им критичарски рад (изузимајући опет Цара) изгледа увелико узгредан” (Витошевић 1975: 8).

Марко Цар је први представио Иполита Тена (Исто: 28), залагао се за ослобођење књижевности од романтике (Исто: 30), критика је била вид ослобођења људске мисли, већ у раду о Кардучију Цар се противи душевном ропству (Исто: 25), залаже се за висока мерила у књижевној критици, а сам постаје жртва сопственог залагања (Исто: 31-32), јер га први напада Скерлић због неоригиналности и у томе му се придружује Бранко Лазаревић.

Значајно је да се Марко Цар први, још 1902. године, залагао за објављивање антологије српске књижевне критике. Таква антологија ће се појавити двадесет и седам година касније из пера Љубомира Петровића, па потом двадесет и девет година из пера Зорана Мишића, па онда антологијски избор чувене едиције Српска кюижевна критика у 25 књига, која је обухватила сваког вреднијег књижевног критичара. Све ове побројане чињенице говоре да ангажовање Марка Цара није никако маргинално.

Често се Цару замерало да је несистематичан, недоследан и поводљив. Витошевић као пример за то наводи Царево признање да није читао Змајеву дечју поезију, али је веровао другима да је добра. Витошевић пише: „Најзад, он ће једном искрено пружити пример овог повођења за општим мишљењем, 
причајући како је Змајево дечје песништво, као и сви, уважавао - а да га није ни читао!" (Витошевић 1975: 47).

Значајно је овде видети шта је тачно написао Марко Цар. Цар пише:

И нек ми буде просто да на овом месту признам једну своју велику грешку. Има већ двадесетак, а ваљда и више година, како овда-онда наилазим на Змајеве дечје песме, а на штету и срамоту своју, морам исповедити да сам ретко када коју читао. Пристајући прећутно уз опште мишљење о њима, ја сам те песме уважавао, а да им, тако рећи, не знађох честито ни садржине. Илустрована антологија Змајовиних дечијих песама, коју је ту скоро издала Српска књижевна задруга у редакцији Г. Милана Шевића, била је за мене, дакле читаво једно откровење. А имао сам шта открити! (Цар 1936: 99-100).

Овај цитат недвосмислено показује Цареву искреност, али и веру у туђе мишљење. Он верује књижевним критичарима и онима који тврде да је нешто добро, иако то што препоручују, сам није прочитао. Ту нема ни говора о поводљивости, већ је реч о поверењу. То показује да је Цару књижевна критика била мера вредности. Цитат показује и да је он прочитао Змајеву поезију за децу. Ту бисмо истакли да је ово један од значајнијих есеја о књижевности за децу. Прво, јер прави пресек о деци у поезији од антике преко ренесансне књижевности све до књижевности XIX века; друго, јер је ово први рад после Шевићеве антологије, у којем се промишља религиозна поезија Јована Јовановића Змаја. Уз то је ово један од првих радова који говори о жанру молитве у уметничкој поезији, а сигурно је, уз Милана Шевића први рад који говори о жанру молитве у Змајевој поезији. Цар је апострофирао песме „Молитва мале Данице” и „Јато звезда”, које ће касније, нарочито крајем прошлог века, бити често истицане као песме од изванредног религиозног значаја (Јашовић 2016). Иако Цар није оправдавао религиозну тенденциозност поезије, нарочито у школству, веровао је да у одсудним тренуцима обесправљеног човека, може помоћи само вера у бога.

Поводом тога истиче:

[...] чак и онда, кад је песникова тежња за катехизацијом и сувише прозирна, као на пр. у песми Јато звезда [...] чак ни у том случају ми не можемо да песнику пребацујемо његов поучни смер; јер ма колико да се неко осећа 'лаички настројен' и да се начелно буни против религиозне наставе, он ипак добро зна да кад човека у невољи сав свет остави, и кад бедник нема више ништа да очекује од људске правде, њему још само остаје да дигне очи к небу (Цар 1936: 103).

Успех Змајеве дечје поезије и њен квалитет долази отуда што је пише:

[...] ретким психолошким разумевањем, језиком простим, па ипак зато, или можда управо зато, поетичним, наш је песник проучавао и опевао тежње и нагоне дечје душе, и настојао да све то упућује на добро. Песник по инстикту, он је најбољи део свог талента и најчистији део своје душе ставио у службу српске деце, коју је пратио и сликао у свим тренуцима њиховог инфатилног живота (Цар 1936: 103-104).

Због оваквих радова и оцена, Витошевић је могао несметано закључити: „У своје доба, пак, ако најчешће и није био дубок и блистав, он је често умео бити пријатан и скоро увек - користан” (Витошевић 1975: 51). Сматрамо да је корисност Марка Цара за науку о књижевности била вишеструка, јер је 
он међу првима направио јасну диференцијацију између есеја и књижевне критике. Као што је познато, Марко Цар није творац есеја, ${ }^{1}$ није ни први садржину своје књиге одредио насловом есеји. Пре њега су то урадили Светислав Стефановић (Есеји из енглеске књижевности, 1907; Портрети и есеји, 1931), Крста Цицварић (Критички есеји, 1912), Милорад В. Јеремић (Есеји из школске политике, 1914), Антон Густав Матош (Фељтони и есеји, 1917), Петар Одавић (Есеји, 1925) и Јулка Ђурђевић Хлапец (Студије и есеји о феминизму, 1935), међутим, Марко Цар је, колико је нама познато, први у оквиру своје књиге Eсеји (1936) конкретизовао жанр есеја, тако што га је јасно одвојио од књижевне критике пишући „Есеј о 'есеју””.

У „Есеју о 'есеју’”, Марко Цар је, рецимо, за разлику од Исидоре Секулић, која је много допринела развоју есеја у српској књижевности у XX веку, а при томе није „разрадила проблематику есеја” (Леовац 1986: 121), целокупан свој, рекли бисмо, мисаони потенцијал усмерио ка одговору на питање: Шта је есеј? Што се самог појма тиче, Цар није улазио у етимологију, нити је тражио извесна генеалошка упоришта овог појма у књижевној традицији. Он је кренуо од једне књижевне појаве у Енглеској коју је намерио да опише и да је представи својој читалачкој публици. Сам његов тон док објашњава сврсисходност есеја чини се бојажљивим, као да је Цар био уверења да је сам есеј далеко од припростог укуса наше читалачке публике. Незаинтересованост за есеј Цар проналази у друштвеним приликама и степену образованости:

Можда би узрок томе јако запажљивом недостатку код нас требало потражити, на првом месту, у нашим још доста скромним друштвеним и културним приликама. Есејистичка литература, као специјалан род, претпоставља и код писца и код публике један ступањ образованости и укуса, до ког ми, у опште говорећи, нисмо још допрли (Цар 1936: 9).

Незаинтересованости за жанр есеја, према Цару, доприноси и састав књижевне публике, њена информисаност и укус:

Публика се код нас, на крају крајева, састоји из једне мале, на страним литературама васпитане елите, и гомиле обичних читалаца. Чији укус и чије знање стоји на нивоу обичне репортаже у политичким новинама. Међутим, док мали број елитних читалаца може да своје умне и естетичке потребе подмирује читањем страних писаца, ширу публику треба-

\footnotetext{
${ }^{1}$ Иако је Доситеј Обрадовић (1739-1811) од почетка нагињао, како поучавању тако и есеју („Писмо Харалампију”, „Прво реци, па гледај те утеци”, „Не кај се добро чинићи”, делови Собранија и Мезимияа, као и делови из Живота), није „признат као творац српског есеја” (Деретић 1997: 175), што Доситеј у суштини јесте, јер је он аутор моралних есеја, аутобиографских есеја, есеја-епистола. Доситеј је есеј назвао према српском језику тога времена наравоучителне веш$m u$, иако је знао за оригинални назив, који је, рецимо, преводио са опити. Истицања је вредно, да поред тога што сматрамо да Доситеј јесте творац модерног, новог, секуларног есеја у српској књижевности, сам есеј као форма није апсолутна новина, јер му генетичко исходиште проналазимо у средњовековним формама поученијима (Трифуновић 1990: 264-271) и посланијима (Исто: 273), а Доситеј се са њима упознао док је читао црквену лектиру. Тако Деретићев закључак да Доситејева наравоученија треба довести у везу са поученијима, а писма-расправе и аутобиграфске есеја са посланијима, само још једном доказује да се један стваралац може разумети како у контексту књижевне традиције из које је проистекао и у којој се формирао, тако и из друштвено-стваралачког контекста актуелности самог аутора.
} 
ло би васпитавати, нудећи јој стално духовну храну изабрану по квалитету, а одличну по форми (Цар 1936: 9).

Ова два цитата су важна јер доказују да неколико значајних појмова из области науке о књижевности јесу били присутни као научна апаратура у првој половини XX века. Прво, књижевно стваралаштво је третирано као јединство текста и контекста, с тим што је текст био подређен контексту. Друго, у књижевно-теоријској концепцији Марка Цара, присутни су писаи, дело и публика. У његовој концепцији и писац и публика су пасивни чланови на које треба извршити извесне утицаје. Није самостално ни дело пошто, пре свега, зависи од друштва у којем настаје. То доказује да је Марко Цар био ближи позитивистичкој концепцији Јована Скерлића, но естетизму Богдана Поповића.

Марко Цар есеј назива „књижевни род”, а не књижевна врста, што је уже од књижевног рода. Сматрамо да ово неразликовање између књижевног рода и врсте није резултат стања у теорији књижевности код Срба, јер су српски књижевни теоретичари углавном баштинили западноевропска, пре свих немачка књижевна достигнућа, као и све балканске књижевности, а као што је познато, они су разликовали родове и врсте још у XVIII, посебно у XIX веку. Миливој Солар за употребу појма књижевног рода истиче да се „u hrvatskom nazivlju nerijetko rabi i za književnu vrstu" (Солар 2012: 390) и да је таква ситуација била чешћа у прошлости. С обзиром на то да је Цар далматинског порекла и да је књижевно васпитаван на примеру италијанске књижевности и живео је у Задру од 1884. до окупације Задра од стране Италијана 1919. године, када је прешао у Београд, где је живео све до смрти 1953. године, можемо закључити да је нешто од теоријског наслеђа са тог поднебља (хрватског) могло остати присутно код њега и пошто је прешао у Београд.

Од значаја је да инсистирајући на књижевном укусу, који се, према њему, не изграђује радом већ се дидактички ствара, Марко Цар непосредно доказује да је естетизам, који је у српску књижевност увео Богдан Поповић, присутан и да је постао један од елементарних захтева књижевних критичара и тежњи писаца лепе књижевности.

Док је Исидора Секулић сматрала да је „есеј лично мишљење” (Секулић 1985: 401), Цар је сматрао да је есеј „компромисна литература” (1936: 7), али не у односу на аутора, или читаоца, већ у односу на садржину есеја, јер је есеј „нешто између елегантне конферансе и опсежне, исцрпне научне расправе" (Цар 1936: 7). Није ништа другачије одређиван есеј ни на плану науке, Милош Илић, рецимо, есеј одређује као „немирну форму” (Илић 1996: 56). То говори да је есеј, као жанр флексибилан, жанровски поливалентан, дефиницијски га није лако обухватити, али је суштински неопходан, како у области имагинативног, тако и у области научног стваралаштва.

Садржину есеја Цар је одређивао и у односу на објекат промишљања, па констатује: „Књижевни есеј то је, укратко казано, напис који нема амбицију да извесан предмет, извесну грађу савлада до краја, а то значи свестрано и исцрпно” (Цар 1936: 9), или: „књижевни есеј није расправа којом се иде затим да се извесан предмет опширно третира и до краја исцрпе” (Исто: 11). 
Шездесет година касније, Милош Илић овако одређује есеј: „то је форма у којој долази до изражаја зрелост тренутка да се поставе извесна питања када још није зрела ситуација да се дају дефинитивнији и коначни одговори на та постављена питања" (Илић 1996: 57). Дакле, дефиниција се само стилизовала, а суштински, стваралачко, теоријско и епистемолошко искуство јој ништа није додало нити одузело. Мишљења смо да је Царев закључак да је од есенцијалног значаја за есеј да је „уметничке природе” (Цар 1936: 14), најтачнија дефиниција есеја, јер управо таква есенцијална природа есеја доприноси да он избегава ограничености дефиниција.

Тиме што је Марко Цар у књизи Есеји, одмах иза уводног „Есеја о 'есеју”” дао дао рад о књижевној критици „Књижевност и критика”, он је направио јасну диференцијацију између есеја и књижевне критике, сматрајући да је књижевна критика значајан „књижевни род” који може бити „књижевнији од свих књижевних родова, зато што је она литератури оно, што је литература животу" (Исто: 24).

Док о есеју пише благонаклоно, са бојазни да случајно не одбије читаоце и будуће ствараоце од есеја, о критици пише снажно, провокативно и отворено. Сматра да никад није било горег писања до у његовој актуелности, те стога критика мора преузимати улогу „овчарског пса” (Исто: 18), али то мора са мером, јер не сме „клице истинског талента да убије у заметку” (Исто: 21). Зато „велики критичари представљају [...] литерарну савест ${ }^{2 ”}$ (Исто: 24).

Критика мора да „узме у заштиту речник” (Исто: 19) и мора да иде „под руку са домаћом литературом и да је потпуно свесна њених почетака и данашњег ступња њеног развитка, пошто једино тако може да се одржи потребна веза између минулих времена и надолазећих нараштаја" (Исто: 19). Овај цитат доказује да је свест о къижевној традицији Томаса С. Елиота, увелико била усвојена у књижевном мишљењу уопште. Значајно је промишљање књижевне традиције експлицирао садржајем есеја 1919. године, а да је временом постало парадигма a priori без које је данас немогуће разумети књижевност и књижевно стваралаштво.

Суштина књижевне критике према Цару није само да суди, нити књижевници треба да се боје ње, већ треба да се остварују у синестетичком прегнућу стварања уметнине, ако критици постане циљ само критиковање и ако само собом представља сврсисходност сви ,јој поричу смисао и утицај на писце и читалачку публику" (Исто: 23). Сматра да критика није ту само да суди и пресуђује, већ ,је дужна да своје пресуде образлаже” (Исто: 25). Права књижевна критика је кад своје пресуде и ставове може јасно и прецизно да саопшти.

Оваквим одређењем књижевне критике у односу на есеј, Марко Цар је показао да у његовом концепту поимања књижевности постоји јасно разграничење између онога што се ствара под обавезом тачности (књижевна критика) и онога што се ствара са стваралачком тежњом ка лепом (есеј). Поред појмова есеја и књижевне критике постоји низ појмова (класично, лите-

\footnotetext{
2 Подвукао М. Цар.
} 
рарна уметност, поезија, укус и лепо) који су промишљани у овој књизи и представљају Царев концепт разумевања књижевног стваралаштва. Можемо закључити да се Марку Цару, без обзира на стилске недостатке, често коришћењу готових, туђих оцена, ипак треба враћати. Тим пре, уколико знамо да је иза себе оставио тринаест књига есеја, огледа и критика, пет књига путописа и три књиге приповедака, које нису увек на висини његових естетичких захтева, било у есеју или критици, али га представљају као једног комплетног ствараоца који је стварао са јасно постављеним циљем који се огледао у несебичној, искреној тежњи ка стварању лепог.

\section{ИЗВОРИ}

Цар 1936: М. Цар, Есеји, Београд: СКЗ.

\section{ЛИТЕРАТУРА}

Витошевић 1975: Д. Витошевић, Кюижевна критика у Скерлићево доба, Нови Сад: Матица српска, Београд: Институт за књижевност и уметност.

Деретић 1983: Ј. Деретић, Историја српске књижевности, Београд: Нолит. Деретић 1997: Ј. Деретић, Поетика српске књижевности, Београд: „Филип Вишњић".

Илић 1996: М. Илић, Научно истраживање, Београд: Филолошки факултет. Јашовић 2016: П. Јашовић, Религиозност у поезији за децу Јована Јовановића Змаја, Детиғство, год. XLII, бр. 2, стр. 54-63.

Леовац 1986: С. Леовац, Кьижевно дело Исидоре Секулић, Београд: Југославија публик „Вук Карџић”.

Палавестра 2008: П. Палавестра, Историја српске књижевне критике, Нови Сад: Матица српска.

Петровић 1929: Љ. Петровић, Антологија српске критике, Београд: Издавачка књижарница Геце Кона.

Секулић 1985: И. Секулић, Сабрана дела књ. 4. Из домаћих књижевности I, Београд: Југославија публик „Вук Карџић”.

Скерлић 1953: Ј. Скерлић, Историја нове српске књижевности, Београд: Рад. Солар 2012: М. Солар, Теорија књижевности са речником књижевног називља, Београд: Службени гласник.

Трифуновић 1990: Ђ. Трифуновић, Азбучник српских средњовековних књижевних појмова, Београд: Нолит. 
Predrag M. Jašović

\section{MARKO CAR, ONTO THEORETICAL AND GENRE DEFINITION OF AN ESSAY}

\section{(Summary)}

The analysis of the book Essays (1936) shows how the work of M. Car essays contributed to the development and determination of this genre in Serbian literature. Dividing the content of the book into three parts showed a creative desire to theoretically determine the genre of the essay, and showing it in some of its basic manifestational forms, not by subject, but instead by the abstraction of the problem. It is interesting that in several essays, by introverted reviewing of their own creative act, self-reliance appears in same essay. Therefore, this book represents the auto-poetic book, which not only introduces the creative process of literary critics, but also the basics of its axiological system. Therefore, we believe that this book is the key to understanding the literary-critical work of Mark Car as a whole. Marko Car is demonstrated in his understanding of the concept of literature, there is a clear demarcation between what is created by the obligation of accuracy (literary criticism) and what is created with the creative aspiration to beauty. 